\title{
Ancient Gypsum Mortars from Ornaments of Seyyed Shams al-Din Mausoleum(Yazd, Iran) Characterization; Identification of Technology of Making
}

Yaser Hamzavi ( $\nabla$ yaserhamzavi99@gmail.com )

Tabriz Islamic Art University https://orcid.org/0000-0002-3504-0534

Behnood Goharbin

ICOM-CC-IRAN

Research article

Keywords: Structural analysis, Gypsum mortar, Mausoleum, Iran

Posted Date: April 5th, 2021

DOI: https://doi.org/10.21203/rs.3.rs-356343/v1

License: (c) (1) This work is licensed under a Creative Commons Attribution 4.0 International License.

Read Full License 


\section{Abstract}

Gypsum mortar in mausoleum of Seyed Shams al-Din in Yazd, shows incomparable reliefs and molded ornaments. A notable instance of these is the partially damaged gypsum inscription that adorns the iwan of the mausoleum and extends over three sides of it. Apposite conservation of this valuable inscription would call for a structural and technological analysis before its structure-related damages and erosion process could be precisely and systematically examined and documented. Samples were obtained from both the surface and deeper layers of the inscription in question as well as the molded gypsum ornament and the fine coat underlying the latter. The samples were then evaluated using XRD, XRF, and SEM-EDS analyses before the mortars were compared. The results revealed that the interior and surface of this inscription vary structurally, which is partly related to the processing of the mortar and executing the inscription and is partly a function of the mortar erosion process. Erosion and structural alterations in the inner inscription are far more extensive than in the surface, leading to the reduced strength, a main reason for it being the permeation of moisture and soluble salts from the retaining wall to the deeper layers of the gypsum inscription.

\section{Introduction}

Gypsum has been a fairly common material for architectural decorations in Iran, especially in the central parts of the country, due to its arid climate. Iranian masters were well able to acquaint themselves with the specific properties of gypsum and gypsum mortar and utilize them, a fact that has resulted in stunning gypsum embellishments. Mortar is a mixture of binding material, aggregate, and water [1]. Iranian stucco working culminated in the eighth century $\mathrm{AH} / 14^{\text {th }}$ century AD. The tradition was widely used in architectural decorations under the llkhanid dynasty over a wide geographic extent, over which brilliant works are now persevered. An eighth century AH structure in the city of Yazd is the mausoleum of Seyed Shams al-Din, which exhibits various techniques of gypsum decorations in the utmost elegance. Notable among these decorations is an inscription in the iwan which extends over the three sides of the latter. The decorative Kufic inscription occurs in the form of mother and child and is topped by a register of floral motifs, with the whole assemblage being executed in relief. Due to its direct exposure to the elements resulting from its location in the open iwan, the inscription has undergone several damages.

As a proper conservation of any historical property requires in the first place a thorough understanding of it, technical analyses of this plaster inscription are thus warranted. Part of the ingenuity of a historical monument lies in the applied raw materials [2], and a precise knowledge of its materials and structure can enable one to provide a correct plan for its restoration interventions and conservation. The main problem of the present study is the lack of technical and structural knowledge of the gypsum ornaments (in this case the Kufic inscription) at the iwan of Seyed Shams al-Din mausoleum in Yazd.

The aim of the present work is thus to attain a technical and structural understanding of the gypsum inscription adoring this iwan. Given the wealth of gypsum ornaments in Iran, especially the conspicuous instances from the eighth century $\mathrm{AH}$, their technical and structural knowledge becomes of great 
importance, and on the other hand, the meager literature on the structure of different types of gypsum decorations from different periods and the outstanding technical questions in this regard are among the matters that warrant the present study. It is noteworthy that the author has planned a targeted research project on the structure and erosion of this particular type of mortar.

\section{Research History}

In an article entitled "Application of Crystallographic Analyses in Technical Studies of Gypsum Historical Monuments (A Case Study of Stuccos from Kuh-e Khwajeh, Sistan, Gypsum Mortar from Shadiakh, Neishabour, and Gypsum Mortar from Alamut Fortress, Qazvin)," Mishmast Nehi supplied information on the gypsum crystals in a sample of historical mortars, using instrumental methods including SEM imaging and XRD analyses [3].

Hamzavi and Sardari in the article "Using Instrumental Analyses to Identify Gypsum Ornaments from Setti Fatemeh Mausoleum, Yazd" subjected a sample of gypsum mortars from the gypsum decorations of the Timurid period in Yazd to technical and structural analyses using XRD fuzzy analysis, XRF elemental analysis as well as SEM. A technical analysis was then applied to the results together and by way of a study of gypsum crystals at different magnifications [4].

Studies have covered the formation and growth of gypsum crystals during setting, proposing some insights: gypsum ${ }^{1}$ crystallizes in the monoclinic system and the prismatic class [5]; gypsum crystals grow in three directions ${ }^{2}$ [6], also $\left(1^{-} 11\right)$ and $\left(1^{-} 03\right)$ forms have convex surfaces and edges [7]; and refractive indices in gypsum crystals are 1.530, 1.523, 1.521 depending on the directions of observation [8].

The formation and development of gypsum crystals occur in three stages: a) when gypsum powder is added to water, it reaches first a saturated and then a supersaturated state; $b$ ) the buds are formed; and c) the growth of crystals then begins in different directions [9]. Gypsum has the ability to crystallize in two forms of gypsum and anhydride [10]. Organic matter, which was customarily intentionally added to the mortar at a certain percentage, affects the number of buds at the beginning and the way the crystals grow during the setting stage [11]. Also, presence of a certain percentage of organic matter and the consequential influence on the W/D ratio $(W / D=$ water/dihydrate) can trigger greater growth of crystals in one particular dimension, resulting in multi-hydral crystals that grow at different speeds in different directions. Organic matter has the greatest effect on the (111) surfaces and its symmetries [12]. In fact, it reduces the number of buds and thereby prevents the growth of crystals along some plates, allowing their growth along other plates.

\section{Research Methods}

In the present study, first field studies and surveys were carried out building on the available written sources, as a result of which, and given the existing problems and conditions, samples were obtained 
from different layers of the ornaments in question. Then, proper laboratory methods were decide on according to the questions at hand. Thus, to identify crystalline phases, powder XRD analysis was carried out qualitatively on 2 mortar samples from the gypsum inscription in the iwan Seyed Shams al-Din mausoleum and 1 sample from the molded gypsum ornaments from the Moqarnas of the outer moqarnas of the iwan for structural comparison with the gypsum inscription. To this end, a PHILIPS PW1800, the Netherlands, X-ray diffractometer (with a cu-target X-ray tube with maximum potential difference of $40 \mathrm{kV}$ and maximum current intensity of $30 \mathrm{~mA}$, fixed sample and needle detector) at an angle of $2 \theta$ and the radiation angle of 5-60 degrees was used. The required analyses were then performed on X'Pert HighScore Plus software. Also, XRF elemental analysis was done in a Philips PW 1480 XRF device, manufactured in 2004, on 2 samples of the gypsum mortar from the iwan inscription. The measurement uncertainty was calculated at $95 \%$ confidence interval and $\mathrm{K}=2$, and LW03 was adopted as testing method. Then, to examine gypsum crystals from the surface and depth of the gypsum inscription and also for spot elemental analysis we used a Phenom ProX SEM (the Netherlands) equipped with multiple acceleration voltages of Kv15, Kv10, Kv5 and an EDS detector, and a EuroEA3000 CHNS Analyzer (EuroVector S.p.A. Co., Italy) that was mounted on the SEM. Finally, the results of the field and library studies were analyzed along with those from the instrumental observations.

\section{Mausoleum Of Seyed Shams Al-din}

Serving as the seat of government and the main center of the dynasty, Yazd witnessed widespread prosperity under the Muzaffarids. New qanats (flumes) and settlements were put up across Yazd, and the city experienced a further development [13] Fig. 1. a. The Muzaffarids acted as vassals of the llkhanid emperors since the reign of Sharaf al-Din Muzaffar to $736 \mathrm{AH}$, and the major Ilkhanid religious buildings emerged between 695-736 $\mathrm{AH}$ [14]. It is notable that the llkhanid architectural style is a direct adaptation from the traditions of the Seljuk period (Wilber 1955).

Seyed Shams al-Din Mohammad, the son of Seyed Rokan al-Din and the son-in-law of Rashid al-Din Fazlullah Tabib, the minister of the llkhanid emperors, commissioned several public buildings in Yazd [13]. Jafari informs us that Seyed Shams al-Din drew the plans of the Chahar Monar School, Dar alSiyadat, the monastery (khangah), bazaar, and bathhouse in Tabriz and send them to Yazd, where master builds began to put up the edifice, and the edifice was fulfilled in $733 \mathrm{AH}$ [15]. Yet, elsewhere he attributes the completion of the edifice to 6 years earlier: The accomplishment of his edifice was in $727 \mathrm{AH}$ [15]. In the The New History of Yazd, Kateb points out that: When Amir Shams al-Din Mohammad gained autonomy in Tabriz, he roughed out the plans of the school, Dar al-Siyadat, Chahar Monar, monastery and bazaar, and sent to Yazd. He appointed the justices of four villages who were his trustees, and they came to Yazd and had the edifice constructed [16]. Mostowfi Bafghi likewise dates the construction of the edifice to $727 \mathrm{AH}:$ "... Seyed Shams al-Din Mohammad put up that sky-scraping edifice in the months of the year 727, and was himself buried within its dome [17] Fig. 1. b.

A notable enterprises of Seyed Shams al-Din is a school erected in the Chahar Monar neighborhood, next to the present-day Howzeh Moltakiyah, and the structure would serve as the burial place of its 
commissioner. At present, that great school and all the belongings of that large complex are simply represented by the dome which houses Seyed's burial chamber and serves as a site of pilgrimage [13]. The mausoleum is a registered National Cultural Heritage. It is notable that the llkhanid mausoleums were typically built, following the earlier traditions, as free-standing structures visible from all sides.

\section{4-1. Architectural Decorations of the Iwan of Seyed Shams al-Din Mausoleum}

Interest in ornamented surfaces in Iranian architecture is no less than that in building forms, and decorative designs display such a sense of unitary between the constituents and the whole that is hardly attested in the linkage of the real building elements [18]. A class of architectural decorations, though not restricted to but possibly originating from Iran where its most fascinating applications occur, concerns gypsum ornaments [19].

From the whole building complex Seyed Shams al-Din commissioned in the Chahar Monar neighborhood only the iwan, parts of the dome (simply the walls), parts of the portal, and a moqarnas alcove attached to the iwan are preserved today Fig. 2.

Measured from the interior, the four walls of the dome are $9.1 \mathrm{~m}$ long, $6.58 \mathrm{~m}$ wide, and $16 \mathrm{~cm}$ thick. The whole walls supporting the dome are covered in striking geometric and floral patterns in paint and gypsum. The designs, decorative brickworks, geometric patterns, cartouches, shamsehs, and borders have been for the most part lost to termite infestation, and cannot be repaired but with great difficulty and excessive cost [13].

The iwan of the mausoleum is about $11 \mathrm{~m}$ long and $6.5 \mathrm{~m}$ wide. It is characterized, among others, by gypsum ornaments that parallel those of the contemporaneous buildings from Yazd. The juxtaposition of the relief and molded gypsum decorations with the murals, as paintings and inked inscriptions, adds to the splendor of the iwan Fig. 3. The exterior facade of the iwan employs a tile mosaic in utmost elegance. The mother and child gypsum inscription in decorative Kufic, gypsum reliefs framing the gypsum inscription and also within the panel over the entrance of the dome, and the qatarbandi (register pattern) and karbandi at the end of the porch are among the other architectural decorations of this iwan. Also attested are two rectangular panels in the ceiling of the iwan, consisting of an overall design of spandrel and cartouche rendered in a combination of mural and molded gypsum decoration. The panels are outlined by the mother and child inscription (the main inscription executed as a mural and the child inscription in coiled gypsum). The wall surfaces exhibit murals with geometric patterns (mostly circles) applied in combination with molded gypsum ornaments, all exhibiting indications of damages.

\section{4-2. Gypsum Inscription in the Iwan of Seyed Shams al-Din Mausoleum}

The inscription is executed in the mother and child manner, with the mother in decorative Kufic and the child in simple Kufic against a ground of arabesques, with a perfect combination of the motifs and scripts. In terms of projection, this ornament has four levels, the highest being the inscription in the decorative Kufic. The decorative area in question is topped by a border of arabesques executed in two 
levels in gypsum relief. The lower margin is formed by a small inscription again in gypsum relief but in a single level, and consists of the repetition of the phrase Al Mulk li Allah Fig. 7.

The text of the gypsum inscription under study is part of surah Al-Fath. It starts from the beginning of verse 22 in the southeast side Fig. 4 and continues in the northeast Fig. 6 and northwest Fig. 5 sides.

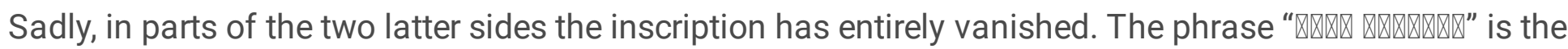
last eligible part on the northwest side. The fact that the main inscription at the iwan consists of some middle verses of a surah is quite odd. Yet, the whole remaining verses of the same surah occur in the ceiling of the iwan, where the mother and child style was likewise adopted. In particular, the first verse up to the end of verse 10 appears in ink. The verses 11 to 21 are executed in gypsum using coiled technique Figs. 4 and 5. Verses 22 to 25 are in the decorative Kufic executed in gypsum relief, while the concluding verses 26 to 29 are embedded as the child within the main inscription. Thus, the whole surah was worked at the iwan of the mausoleum in three different techniques and as four separate inscriptions.

\section{Materials And Methods}

In laboratory studies seeking to determine the structure and the composition of the different layers of the gypsum inscription at the iwan, samples were prepared both from the surface and deeper layers of the inscription, the molded gypsum decoration, and the underlying gypsum lining Table 1 . The present research adopts an experimental development method, drawing on both field and laboratory studies. As part of the field study, the present situation was recorded and observations were made regarding the building in question. This was followed by gaining technical insights into the different layers of the gypsum inscription in light of the results from the analytical examinations.

Table 1: Sampling spots/levels, types of analysis, and sample coding

\begin{tabular}{|lllll|}
\hline & $\begin{array}{l}\text { Surface of the } \\
\text { gypsum } \\
\text { inscription }\end{array}$ & $\begin{array}{l}\text { Depth of the gypsum } \\
\text { inscription }\end{array}$ & $\begin{array}{l}\text { Molded gypsum } \\
\text { ornament }\end{array}$ & $\begin{array}{l}\text { Gypsum } \\
\text { substrate } \\
\text { (fine coat or } \\
\text { finishing) }\end{array}$ \\
\hline XRD & Cod: SS.1 & Cod: SD.1 & Cod: SM.1 & - \\
\hline XRF & Cod: SS.2 & Cod: SD.2 & - & - \\
\hline $\begin{array}{l}\text { SEM- } \\
\text { EDS }\end{array}$ & Cod: SS.3 & Cod: SD.3 & Cod: SM.2 & Cod: SF.1 \\
\hline
\end{tabular}

Given the decidedly complex manner of execution (viz. mother and child style), the distinct stylishness, and in some parts the considerable depth (ranging between 10-20 cm) of the gypsum inscription, it was important to gain insights into the structural characteristics and compositions of the surface and deeper levels of the inscription. Of the three parts of the iwan over which the inscription extends, the extensively damaged middle part was selected for sampling as it provided easier access to the underlying layers. 
Three samples were taken from the surface of the inscription and three more were obtained at $12 \mathrm{~cm}$ depth of it. Also, in order to compare the two types of gypsum decorations used in the building in terms of crystalline structure and mineral compositions, additional samples were collected from the molded gypsum ornaments within the Moqarnas and from the gypsum lining in the first alcove adjoining the iwan Fig. 8 gypsum was used with different percentages and methods depending on the layer, allowing surprising and varied results to be obtained, adapted to the needs of the various masters active in the period [20].

\section{Findings}

XRF analysis: Sample SD.2 was subjected to elemental analysis. The identified oxide elements are given in Table 2. The major elemental composition relates to $\mathrm{SO}_{3}, \mathrm{CaO}$ and $\mathrm{SiO}_{2}$. Elemental analysis was also done on sample SS.2 to allow comparison of the samples deriving from the surface and deeper levels of the gypsum inscription. The observed major elemental composition here was again $\mathrm{SO}_{3}, \mathrm{CaO}$ and $\mathrm{SiO}_{2}$. In the preparation stage, the sample with a grain size of $63 \mu \mathrm{m}$ was heated to $105^{\circ} \mathrm{C}$ so that parts of the volatile elements and compounds (organic matter and carbon in minerals) were removed at a certain temperature and a fixed sample mass was obtained, which is shown as "Loss on Ignition" [21] in Table 2.

Table 2: Results of XRF elemental analysis for samples SD.2 and SS.2

\begin{tabular}{|c|c|c|c|c|c|c|c|c|c|c|c|}
\hline $\mathrm{Cl}$ & L.0.I & $\mathrm{SO}_{3}$ & $\mathrm{P}_{2} \mathrm{O}_{5}$ & $\mathrm{MgO}$ & $\mathrm{K}_{2} \mathrm{O}$ & $\mathrm{Na}_{2} \mathrm{O}$ & $\mathrm{CaO}$ & $\mathrm{Fe}_{2} \mathrm{O}_{3}$ & $\mathrm{Al}_{2} \mathrm{O}_{3}$ & $\mathrm{SiO}_{2}$ & $\begin{array}{l}\text { Elem } \\
\text { Sam }\end{array}$ \\
\hline ppm & $\%$ & $\%$ & $\%$ & $\%$ & $\%$ & $\%$ & $\%$ & $\%$ & $\%$ & $\%$ & \\
\hline 825 & 6.35 & 50.42 & 0.067 & 0.42 & 0.21 & 0.11 & 35.59 & 0.32 & 0.82 & 5.42 & SD.2 \\
\hline 1722 & 17.05 & 44.01 & 0.066 & 0.49 & 0.19 & 0.20 & 31.86 & 0.42 & 0.81 & 4.56 & SS.2 \\
\hline
\end{tabular}

XRD analysis: A fuzzy analysis was performed on sample SD.1, whereby anhydrite was recognized as the major phase in the depth of the gypsum inscription. The identified minor and trace phases were calcite, quartz, gypsum, albite and muscovite-illite Fig. 9.

The fuzzy analysis on sample SS.1 revealed that the major phases in the surface of the gypsum inscription included anhydrite and gypsum, while minor and trace phases consisted of quartz, microcline, albite, montmorillonite and muscovite-illite Fig. 10. The same analysis on sample SM.1 showed gypsum representing the major phase for the molded gypsum ornament, and anhydrite, quartz, basanite, and montmorillonite constituting the minor and trace phases Fig. 11; Table 3. 


\begin{tabular}{|c|c|c|c|c|}
\hline \multirow[b]{3}{*}{ Date: 23.08 .2017} & SM.1 & SS.1 & SD.1 & Sample \\
\hline & $\sqrt{ }$ & $\sqrt{ }$ & $\sqrt{ }$ & Anhydrite \\
\hline & - & - & $\sqrt{ }$ & Calcite \\
\hline $\mathrm{kV}=40$ & $\sqrt{ }$ & $\sqrt{ }$ & $\sqrt{ }$ & Quartz \\
\hline $\mathrm{mA}=30$ & $\sqrt{ }$ & $\sqrt{ }$ & $\sqrt{ }$ & $\mathrm{CaSO} 4,2 \mathrm{H} 2 \mathrm{O}$ \\
\hline $\mathrm{Ka} .=\mathrm{Cu}$ & - & $\sqrt{ }$ & $\sqrt{ }$ & $(\mathrm{Na}, \mathrm{Ca})(\mathrm{Si}, \mathrm{Al}) 4 \mathrm{O} 8$ \\
\hline Fil. $=\mathrm{Ni}$ & - & $\sqrt{ }$ & $\sqrt{ }$ & $\mathrm{KAl} 2 \mathrm{Si} 3 \mathrm{AlO} 10(\mathrm{OH}) 2$ \\
\hline & - & $\sqrt{ }$ & & Microcline \\
\hline Major Phase(s) & $\sqrt{ }$ & $\sqrt{ }$ & - & $\begin{array}{l}\text { Montmorillonite } \\
\qquad \mathrm{Ca} 0.2(\mathrm{Al}, \mathrm{Mg}) 2 \mathrm{Si} 4 \mathrm{O} 10(\mathrm{OH}) 2, \mathrm{xH} 2 \mathrm{O}\end{array}$ \\
\hline Minor Phase(s) & $\sqrt{ }$ & - & & $\mathrm{CaSO} 4,0.5 \mathrm{H} 2 \mathrm{O}$ \\
\hline
\end{tabular}

EDS analysis: Spot elemental analysis was done on samples SS.3, SD.3, SM.2 and SF.1. Microscopic images of the analyzed areas are given in Table 4, where the identified elements are presented as oxide compounds. $\mathrm{SO}_{3}$ and $\mathrm{CaO}$ represent oxide compounds that were identified in all samples at high levels. These oxide compounds might relate to different phases of gypsum.

Table 4: Results of EDS spot elemental analysis on samples SS.3, SD.3, SM.2 and SF.1 


\begin{tabular}{|c|c|c|c|c|c|c|c|}
\hline Sam & $\mathrm{SiO}_{2}$ & $\mathrm{Al}_{2} \mathrm{O}_{3}$ & $\mathrm{Fe}_{2} \mathrm{O}_{3}$ & $\mathrm{CaO}$ & $\mathrm{MgO}$ & $\mathrm{SO}_{3}$ & SEM pic. \\
\hline & $\%$ & $\%$ & $\%$ & $\%$ & $\%$ & $\%$ & \\
\hline SS.3 & 1.57 & - & - & 34.37 & - & 44.1 & \\
\hline SD. 3 & - & 0.15 & - & 33.67 & 0.4 & 45.77 & \\
\hline SM.2 & 4.08 & 1.62 & 0.9 & 32.62 & - & 40.76 & \\
\hline SF.1 & 3.69 & - & 2.09 & 32.64 & 0.21 & 41.35 & \\
\hline
\end{tabular}

SEM Imaging: Images at varying magnifications were acquired from the four samples SS.3, SD.3, SM.2, and SF.1. Given the presence of an original layer of slip and a further coating connected to later restorations on the gypsum inscription, the sampling started at depth of $0.5 \mathrm{~cm}$ from the surface and continued down the lower levels, and images were obtained from its crystal structure at 1000x, 2000x and 5000x. Images at similar magnifications were prepared so as to compare the crystal structures of the different levels of the gypsum inscription mortar (given its great thickness). Likewise, due to the differences in materials, processing, and manner of execution between the gypsum inscription and the molded gypsum ornament, images at 1000x and 2000x were also prepared from the latter for comparison purposes. Because of the distinctive nature of the gypsum fine coat (finishing) used in the Muzaffarid buildings in $\mathrm{Yazd}^{3}$, images were captured from the gypsum lining beneath the molded ornament at 1000x, 3000x and 5000x magnifications Table 5.

Table 5: SEM images at 1000x, 2000x and 5000x magnifications of the crystal structure of samples SS.3, SD.3, SM.2, and SF.1 


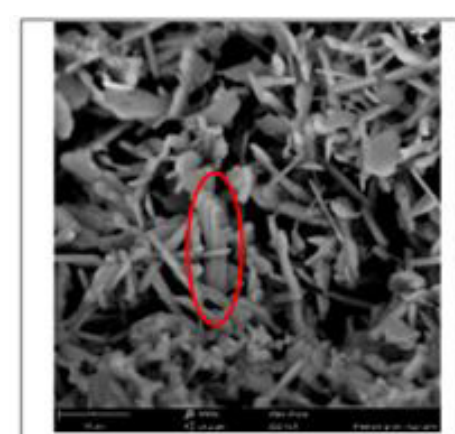

$5000 \mathrm{X}$

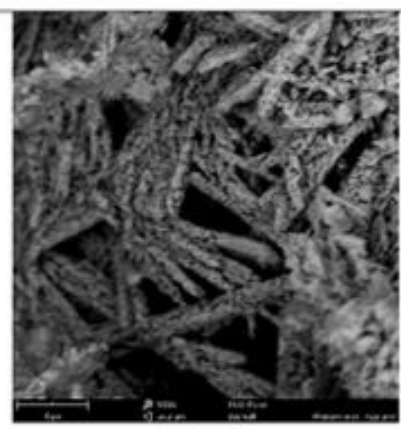

$5000 \mathrm{X}$

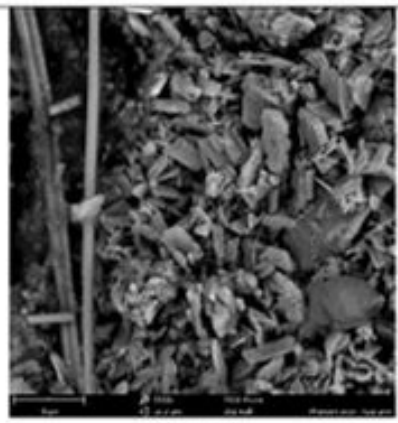

$5000 \mathrm{X}$

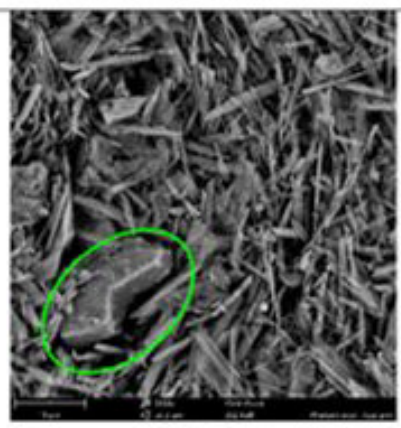

$5000 \mathrm{X}$

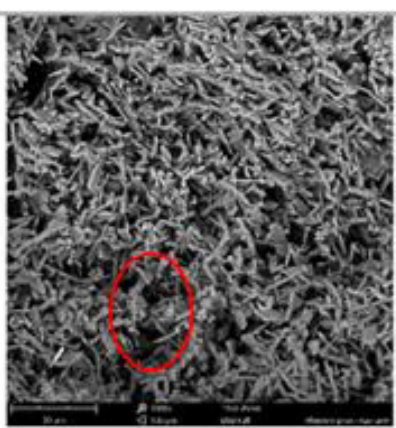

$2000 \mathrm{X}$

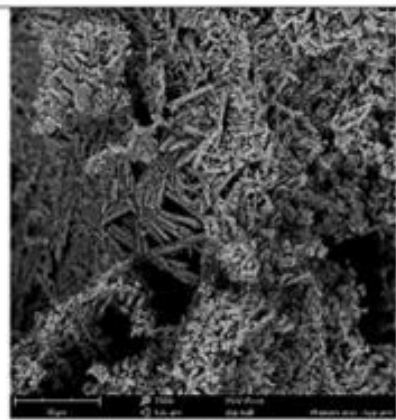

$2000 \mathrm{X}$

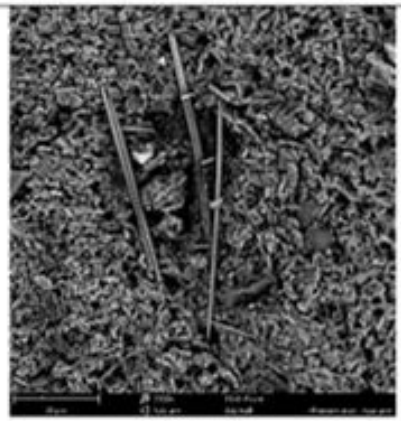

$2000 \mathrm{X}$

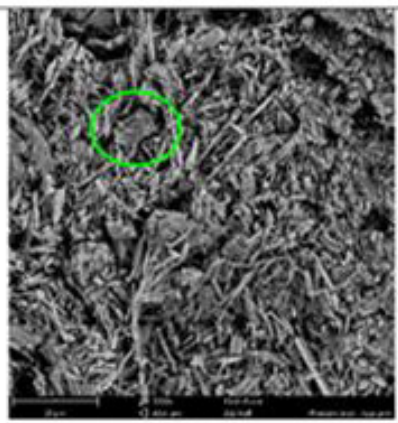

$3000 \mathrm{X}$

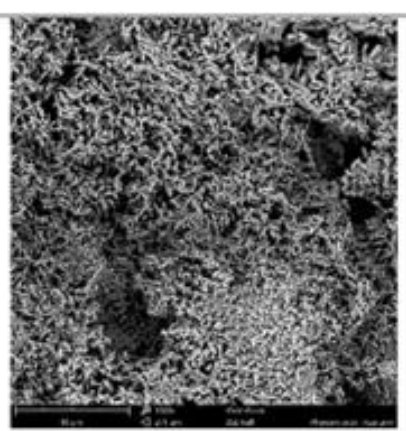

$1000 \mathrm{X}$

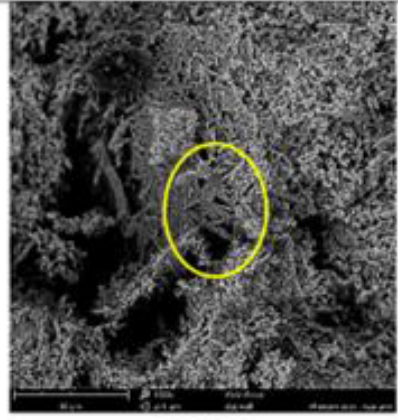

$1000 \mathrm{X}$

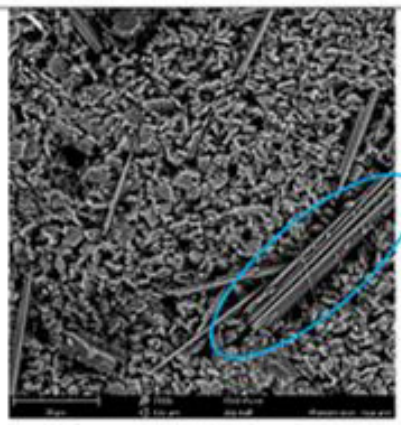

$2000 \mathrm{X}$

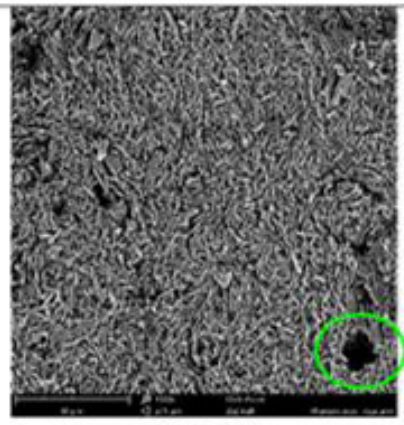

$1000 \mathrm{X}$
SS.3

SD. 3

SM.2

SF.1

\section{Discussion}

A. Depth of the Gypsum Inscription: The XRF analysis shows that Sample SD.2 contains $50.42 \%$ of $\mathrm{SO}_{3}$ and $35.59 \%$ of $\mathrm{CaO}$. Given the sulfur and calcium contents of calcium sulfate and the atomic mass of these elements, one can surmise that $71.42 \%$ of the calcium oxide composition is related to calcium. In the sample in question, calcium accounts for $25.14 \%$ of the total elements; and $40 \%$ of the sulfur trioxide composition is related to sulfur, hence $20.16 \%$ of the total elements being related to sulfur. Given the 
40:32 Ca:S ratio of the $\mathrm{CaSO}_{4}$ composition, by a ratio calculation one may conclude that $25.2 \%$ of the calcium can complete the composition together with sulfur and oxygen, and that the remaining calcium content, viz. $0.21 \%$, can be related to other compounds such as calcite. The $\mathrm{SiO}_{2}(42.5 \%)$ as well as the very low levels of oxide compounds of aluminum, iron, magnesium, sodium and potassium might either derive from the soil added to the gypsum or be connected with the impurities in the natural gypsum ore.

EDS elemental analysis of Sample SD.3 involved its observation at 400x magnification with a particular focus on the areas with porosities and cavities as they could offer a better picture of the structure of the crystals. Very low levels of aluminum and magnesium oxides were detected, not to mention the sulfur and calcium oxides, which are the major constituents of gypsum. By calculating the atomic mass and the ratio of elements in the gypsum composition (hydrated calcium sulfate), the sulfur and calcium were found to comprise respectively $18.3 \%$ and $24.1 \%$ of the total composition. Yet, such sulfur content in a gypsum composition would simply require $22.87 \%$ of calcium. The remaining $1.23 \%$ may thus be related to calcite or other calcium-containing compounds.

The XRD analysis of Sample SD.1 suggests the presence of the dominant anhydrite phase in this part of the inscription, an observation that in turn might point to the following two facts. First, because of the considerable thickness of the inscription, the builders had decided to work the lowest layers out of burnt gypsum (given its lower cost and inactivity in the hydration process), which is usually anhydrite [22], and the presence of an anhydrite content in the gypsum mortar was commonplace. Second, under certain conditions, e.g. at temperature range from 40 to $80^{\circ} \mathrm{C}$, under pressure, and sometimes in the presence of specific salts, gypsum phase may transform to basanite over time [23]. The loose, powdery deeper layers of the inscription further highlighted the hypothesis of fuzzy conversion in this part. Anhydrite crystals were presumed to be visible in high magnification images. The sample was first examined at 400x (SEM), which was followed by preparing 2000x and 5000x magnification images from a selected point of the crystal structure. As it is seen in the related illustration in Table 5, intertwined acicular crystals have grown together in the form of gypsum crystals, which does not correspond well to the result of fuzzy analysis. Closer analysis reveals microcrystals inside the gypsum crystals, which can be interpreted as anhydrite crystals drawing on the result of the XRD phase analysis. This crystal habit might be linked to pseudomorphism [24]. Previous studies have reported that the plastering mortars are usually composed of non-hydraulic or slightly hydraulic lime, sometimes in combination with gypsum or pozzolanic materials along with siliceous, calcareous or basaltic aggregates[25].

A tenable explanation to this observation is that the gypsum crystals formed during the processing of gypsum mortar and its setting were partly transformed over the years, due to pressure and fluctuations in temperature and humidity [26], into anhydrite, a phase alteration in which the shape of the gypsum crystal remained intact whilst the atomic arrangement and chemical formula were affected. This type of crystal is usually termed as anhydrite pseudomorph after gypsum.

The minor phases attested in sample SD.1 in the XRD analysis are as follows: The first concerns calcite, which based on the elemental analyses of the same sample occurs at a very low percentage, a situation

Page $11 / 26$ 
typical to gypsum mortars. Gypsum was identified in other minor phases. It was expected to be a dominant phase, but owing to the existing conditions and the fact that the sample was taken from the depth of the inscription, it proved to be very scanty. Quartz, albite and muscovite-illite are the phases of the soil that in light of the XRF analysis show very low contents.

B. Surface of the Gypsum Inscription: In light of the XRF analysis of Sample SS.2, it contained $44.01 \%$ $\mathrm{SO}_{3}$ and $31.86 \% \mathrm{CaO}$. Given the sulfur and calcium proportions in calcium sulfate and the atomic masses of these elements, one may argue that in this sample $22.75 \%$ of the total elements are related to calcium while $17.64 \%$ belong to sulfur. Based on the calcium to sulfur ratio in $\mathrm{CaSO}_{4}$, the $17.64 \%$ sulfur content would require $22.5 \%$ of calcium. Thus the remaining calcium content in the sample, i.e. $0.25 \%$, can be related to other compounds such as calcite. Other notable oxide compound is $\mathrm{SiO}_{2}(4.56 \%)$, which is a common ingredient in traditional gypsum mortars (traditional master builders often added required amount of soil to gypsum mortar). Also, the meager presence of aluminum and iron oxide compounds and other elements may be related either to the soil added to gypsum or the soil impurity associated with the original ore Table 3.

In the EDS elemental analysis of sample SS.3, other than sulfur and calcium oxides, only a small content of silicon oxide was detected Table 4. Whilst XRF produced similar results for the samples from both the depth and surface of the gypsum inscription, results from this analysis are considerably contradictory as far as minor oxide compounds are concerned. The predominant phases identified in the XRD analyses for SS.1 are anhydrite and gypsum. The mentioned variances in the minor phases between the samples from the surface and deeper levels, among others, includes the fact that, unlike SD.1, here calcite was not detected. Similarly, the attested microcline (with a triclinic crystal system and silicate crystal order) and montmorillonite phases Table 2 were absent in the sample from the deeper level. However, judging from the elemental analysis, these compounds are simply represented in SS.1 by very small percentages.

Examining crystals in images at varying magnifications revealed intertwined acicular gypsum crystals, where an aggregate of crystals in smaller dimensions. The gypsum crystals in this sample show lower growth than those of SD.3, perhaps due to the presence of calcite and salts in the deeper levels of the inscription. At times, even in the presence of acid or saline solutions in the environment, semi-hydrated gypsum is formed in the absence of pressure and at normal summer temperatures [8]; calcite also slows down setting of gypsum mortar [27], a fact that elicited the greater crystal growth.

C. Molded Gypsum Ornament: Given the differences in the execution techniques and appearances of the molded gypsum ornament and the gypsum inscription, this comparative analysis can provide the reader with a more clear picture of the gypsum in terms of composition and crystallography. EDS elemental analysis was performed on sample SM.2. The analysis showed that, apart from sulfur and calcium oxides that occurred in high proportions, silicon oxide was detected at about $4 \%$ and aluminum and iron oxides at a meager level. The measured atomic mass and the relative proportion of the elements in the gypsum composition (calcium sulfate) revealed a sulfur content of $16.3 \%$ in the whole composition and a calcium content of $23.3 \%$. Since such sulfur percentage in gypsum composition will merely require 
$20.37 \%$ of calcium, the remaining $2.93 \%$ calcium might be attributed to such calcium-containing compounds as montmorillonite.

XRD analysis detected gypsum as the predominant phase in sample SM.1, where anhydrite and basanite were among the notable minor phases. In the previous two samples, no traces of basanite were identified. Quartz and montmorillonite were other minor phases in this historical sample. Other minor phases attested in the previous specimens were absent in this sample. In other words, the type of the soil that was either added intentionally or existed as impurity in the plaster mortar of the inscription differs from the one used in the specimen in question.

The crystals of sample SM. 2 were also subjected to SEM observation. The gypsum crystals proved to differ from those of the previous specimens in that here they lacked the acicular habit. A peculiar characteristic of an anomalous gypsum crystal structure is the formation of a network of coarse crystals instead of conventional acicular ones [28]. The squat habit exhibited by the crystals in sample SM.2 meant that they had grown excessively in the second and third dimensions. This happens when the gypsum mortar becomes slow-set. A notable fact about the SEM images is the plant fibers interspersed among the crystals Table 5.

It is noteworthy that the organic matter added to the gypsum mortar as an additive in the processing phase causes crystals to grow in different directions, usually giving the acicular gypsum crystal a squat habit. The degree of crystal thickening is contingent on the amount of organic matter [12]. In light of field studies and microscopic observations of gypsum specimens from various historical monuments in Iran, plant fibers were not customarily applied to the mortar of gypsum reliefs.

The molded gypsum ornaments in the mausoleum of Seyed Rokan al-Din (the father of Seyed Shams alDin) have been the subject of several studies, parts of their results can be summarized as the following: To enhance the structural strength of these gypsum ornament and slowing the setting time to allow an extended working time for molding operation, colloid was added during the processing of the mortar. Since introducing colloid turns gypsum into a retarded mortar [27] and given the considerable comparisons of the molded gypsum ornaments in both concerned buildings, one may logically ascribe the organic content in the SEM images from sample SM.2 to colloid.

Further, in the image at 5000x there are discernible a series of gypsum crystals with parallel, superimposed (010) planes. In this context, Mishmasht Nehi puts that: SEM images of koshteh gypsum display a large number of gypsum crystals perceptible from the (010) plane surface. In this structure, the size and shape of the crystals are similar and irregular and non-crystalline structures are absent in SEM images. The appearance of gypsum crystals from the (010) plane surface indicates that the gypsum crystals in this composition were rearranged in parallel layers and their (010) planes were placed on top of each other [3]. By juxtaposing the images at different magnifications as well as the available information, the plaster in question was apparently processed as a slow-setting gypsum mortar. 
D. Gypsum fine coat (finishing): EDS elemental analysis on sample SF.1 (coming from the thin layer of the gypsum lining) showed that the major oxide compounds were sulfur and calcium, while the minor oxide compounds included silica, aluminum and magnesium. In this specimen, other soil-related elements are witnessed apart from gypsum elements. The presence of magnesium may be related to the filler of the bedding layer. White clay was frequently used as a filler, and occasionally huntite, $\mathrm{Mg}_{3} \mathrm{Ca}\left(\mathrm{CO}_{3}\right)_{4}$, served the same function [29]. It can thus be assumed that the filler used in the bedding layer in this part of the architectural decoration is huntite.

The crystals of sample SF.1 appear as intertwined needles, and this growth has occurred in different directions. The empty spaces between the crystals are infrequent, giving an expression of sufficient coherence. Twin crystals occur at one point Table 5. Whilst the most common twinning form in natural gypsum is swallowtail twin, in our specimen a different form (101) Montmartre twin or macle) is evident, and a reflection symmetry of the gypsum crystal is witnessed.

Of the four specimens subjected to elemental analysis in this study, samples SF.1 and SD.3 contained $\mathrm{MgO}$ and samples SF. 1 and SS. 3 lacked the oxide compound $\mathrm{Al}_{2} \mathrm{O}_{3}$. In light of the EDS analyses, iron oxide composition occurred only in two specimens, SM.2 and SF.1, whilst the XRF analyses detected iron in the both specimens deriving from the gypsum inscription.

\section{Conclusions}

On account of the physical and chemical properties of gypsum crystals, the structural examination and erosion process of gypsum decorations in the iwan of Seyed Shams al-Din mausoleum were investigated at one go. Our findings suggest that the gypsum inscription in this iwan, due to its considerable thickness, show differences between its surface and deeper levels in structure and constituent elements as it is. These differences may be attributed partially to the execution technique and partially to its (chemical and physical) alteration and erosion processes. In fact, because of the different conditions prevailing in the surface and deeper levels of the inscription, the deeper levels underwent more structural changes, and therefore became less robust and the gypsum mortar has got more powdery.

In the depth of the gypsum inscription there is a smaller calcite phase. Two main possible explanations may be: a lime content added to the mortar during its processing; or the calcium carbonate infiltrated into the mortar structure over time from the retaining wall. Our analyses (elemental characterizations and microscopic observations), the fact that the main phase in the deeper levels of the gypsum inscription is anhydrite, the presence of magnesium in the inner matrix of the inscription, and the evidence of anhydrite pseudo morph after gypsum, all combine to suggest that the latter explanation as more plausible.

To gain a better insight into the gypsum inscription mortar, it was compared to the mortars of the molded gypsum ornament and the bedding of this latter ornament. The main phase in the molded ornament is gypsum. Unlike the gypsum inscription, the molded ornament has apparently not experienced a phase alteration thanks to its rather low thickness, the particular technique involved in its processing, and 
perhaps the presence of organic matter and iron-rich soil (which varies from the gypsum inscription mortar). The gypsum mortar in the base layers (on which the molded ornament was placed) shows a quick set crystal structure. It is of tremendous significance that the master plasterer was able to apply successfully a thin film of gypsum (of about $2 \mathrm{~mm}$ ) to coat the Moqarnas as a quick setting gypsum paste. The crystal structure of the gypsum bedding contrasts that of the molded ornament, and in terms of dimensions, the bedding layer exhibits smaller and narrower crystals when compared to those of the mortar (in both surface and deeper levels) of the inscription in the iwan.

Upon close examination using plaster and dentist's instruments, the higher strength of the surface layers of the gypsum inscription in relation to its deeper levels is outright evident. For future studies, it is suggested that the level of mortar resistance of the surface and deeper levels of the inscription be carefully examined and identified via physical studies to furnish a picture of this aspect of the monument as well drawing on the findings of the present study.

Suggestions for future research: Given the wealth of gypsum ornaments in Iran that span in date the Parthian to the contemporary period and have not been covered by extensive research to explore their technical aspects, structural, technological and pathological studies of these monuments are offer proffer able to enable completing the database of this field over time.

\section{Declarations}

\section{Competing interests}

The authors declare that they have no known competing financial interests or personal relationships that could have appeared to influence the work reported in this paper.

\section{Funding}

We have no fund.

\section{Acknowledgment}

The author wishes to extend his gratitude to Messrs Parviz Helakouie, Moslem Mishmast Nehi, Mohammad Sha'rbaf, Majid Olumi, Ali Mohammad Sardari Zarchi, Farshad Mo'azeni and Miss Fatemeh Salahshour for their generous help.

\section{Notes}

\section{Calcium sulfate dehydrate, $\mathrm{CaSO} 4.2 \mathrm{H} 2 \mathrm{O}$}

2. Gypsum crystals tend to extend transversely along the [010] direction and longitudinally along the Zaxis direction. The typical forms assumed by ordinary gypsum crystals are: [010], [110] and [111] (Gourdin and Kingery 1975). 
3 . The gypsum fine coat (finishing) at Seyed Rokn al-Din mausoleum in Yazd with a thickness of about 2 $\mathrm{mm}$ is executed on a thatch, fine coat. Technical examinations have revealed that the mortar in question was prepared as a quick setting compound. The fact that a very thin layer of plaster was applied over a fairly vast area, and that in a quick setting form, is quite interesting (Hamzavi and Vatandoust 2014, 314-321). The gypsum fine coat at the tomb of Seyed Sham al-Din is of the same thickness.

\section{References}

[1] M. K. Donais, M. Alrais, K. Konomi, D. George, W. H. Ramundt, E. Smith, Energy dispersive X-ray fluorescence spectrometry characterization of wall mortars with principal component analysis: Phasing and ex situ versus in situ sampling. Journal of Cultural Heritage 43 (2020) 90-97.

[2] International Cultural Tourism Charter Managing Tourism at Places of Heritage Significance (1999). Adopted by ICOMOS (International Council on Monuments and Sites).

[3] M. Mish Masti Nehi, The Application of Crystallographic Interpretation on Technical Study of GypsumBased Historical Materials (Case studies of stucco decoration of Kuh-e Khwaja and Gypsum Mortars from Shadiakh and Alamut). Journal of Research on Archaeometry, 1, 2 (2016): 1-14. (In Persian) (DOI: 10.29252/jra.1.2.1).

[4] Y. Hamzavi, A. Sardari, Using instrumental analyzes to identify gypsum arrays of the tomb of Seti Fatemeh Yazd. Book of Proceedings of the First Conference on Materials Science and Preservation of Cultural-Historical Monuments March 31, 2012: Research Institute of Cultural Heritage, Handicrafts and Tourism, (2011). Tehran, Iran. (In Persian).

[5] H. Sudell, The complete Guide to Rocks \& Minerals. Project Editor: Catherine Stuart, (2010). London: Hermes House.

[6] W. H. Gourdin, W. D. Kingery, The beginnings of pyrotechnology: Neolithic and Egyptian lime plaster. Journal of Field Archaeology, 2(1-2), (1975): 133-150.

[7] L. Sanna, P. Forti, S. E. Lauritzen Preliminary U/TH dating and the evolution of gypsum crystals in NAICA cave (Mexico). Acta Carsologica 40/1, (2011):17-28.

[8] N. B. Singh, B. Middendorf, Calcium sulphate hemihydrate hydration leading to gypsum crystallization. Progress in Crystal Growth and Characterization of Materials 53 (2007): 57-77.

(DOl:10.1016/j.pcrysgrow.2007.01.002)

[9] E. A. Abdel-Aal, M. M. Rashad, H. El-Shall, Crystallization of calcium sulfate dehydrate at different supersaturation ratios and different free sulfate concentrations. Crystal Research and Technology, 39(4), (2004). 313-321. (DOI:10.1002/crat.200310188) 
[10] G. Torraca, Lectures on Materials Science for Architectural Conservation. Getty Conservation Institute, (2009). Los Angeles, CA.

[11] B. Middendorf, Physico-mechanical and microstructural characteristics of historic and restoration mortars based on gypsum: current knowledge and perspective. Geological Society, London, Special Publications, 205(1) (2002). 165-176.

[12] Li, Jianquan; Li, Guozhong; Yu, Yanzhen, The influences of gypsum water-proofing additive on gypsum crystal growth. Materials Letters, 61, 3 (2007): 872-876.

[13] I. Afshar, Yazd Memorabilia. Second Edition, (1995). Tehran: Association of Cultural Works and Honors.

[14] Sh. Blair, J. M. Bloom, Islamic Art and Architecture. (2006). Publisher: McMullen Museum of Art. [15] J. Jafari, History of Yazd. Edited by Iraj Afshar, 1959, (15th century). Tehran: Book Translation and Publishing Company.(In Persian)

[16] A. Kateb, New history of Yazd. Edited by Iraj Afshar, third edition, 2007, (15th century). Tehran: Amirkabir.(In Persian)

[17] M. Mostowfi Bafghi, Jame Mofidi. Edited by Iraj Afshar, 1960, (1679). Tehran: Rangin.(In Persian)

[18] D. N. Wilber, The Architecture of Islamic Iran: The IIKhanid Period. (1955). Princeton University Press.

[19] D. Hill, 0. Grabar, Islamic Architecture and its Decoration AD 800-1500 Hardcover - Import, November 1, ISBN-13 : 978-0571046423, (1967). Published online by Cambridge University Press: 24 December 2009.

[20] M. Caroselli, G. Cavallo, A. Felici, S. Luppichini, G. Nicoli, Gypsum in Ticinese stucco artworks of the 16-17th century: Use, characterization, provenance and induced decay phenomena Lucia Aliverti, Giacinta Jean. Journal of Archaeological Science: Reports, 24 (2019): 208-219.

[21] J. I. Santisteban, R. Mediavilla, E. Lo pez-Pamo, C. J. Dabrio, M. B. Ruiz Zapata, M. J. Gil Garcia, S. Castano, P. E. Martınez-Alfaro, Loss on ignition: a qualitative or quantitative method for organic matter and carbonate mineral content in sediments? Journal of Paleolimnology, 32, 3 (2004). DOI:

10.1023/B:JOPL.0000042999.30131.5b

[22] I. P. Cardoso, E. Pye, Gessoes in Portuguese Baroque gilding grounds, part 1: a study of historical documentary sources. Studies in Conservation, 62, 4 (2017): 158-209.

[23] P. Ballirano, E. Melis, Thermal behaviour and kinetics of dehydration of gypsum in air from in situ real-time laboratory parallel-beam X-ray powder diffraction. Physics and Chemistry of Minerals, 36 (2009): 391-402. 
[24] C. Klein, S. Cornelius, Jr. Hurlbut, Manual of Mineralogy. (1998). New York City: Published by John Wiley \& Sons Inc, ISBN 13: 9780471312666.

[25] S. Divya Rani, Manu Santhanam, Sangeeta Bais. Historic incised plasterwork of India Characteristics

and microstructure. Construction and Building Materials 221 (2019): 253-262.

[26] M.R. Valluzzi, A. Bondî, F. da Porto, P. Franchetti, C. Modena Structural investigations and analyses for the conservation of the 'Arsenale' of Venice. Journal of Cultural Heritage, 3 (2002): 65-71.

[27] Y. Ennaciri, F. E. Mouahid, A. Bendriss, M. Bettach, Conversion of phosphogypsum to potassium sulfate and calcium carbonate in aqueous solution. MATEC Web of Conferences 5, 04006 (2013). (DOI: 10.1051/matecconf/20130504006)

[28] B. Middendorf, C. Vellmer, M. Schmidt, Take a closer look: Calcium sulphate based building materials in interaction with chemical additives. In Nanotechnology in construction, Editors: Peter, J. M. Bartos; John, J. Hughes; Pavel, Trtik; Wenzhong, Zhu; (2004). Cambridge: The Royal Society of Chemistry, pp: 263-272.

[29] Y. Hamzavi, Characterization of gypsum mortar of Seyyed Shams-din Monument in Yazd, Iran (Kufic inscription, molded gypsum decoration, finishing plaster).Maremat \& Memari-e Iran, 25, 2 (2021).(In Persian)

\section{Figures}
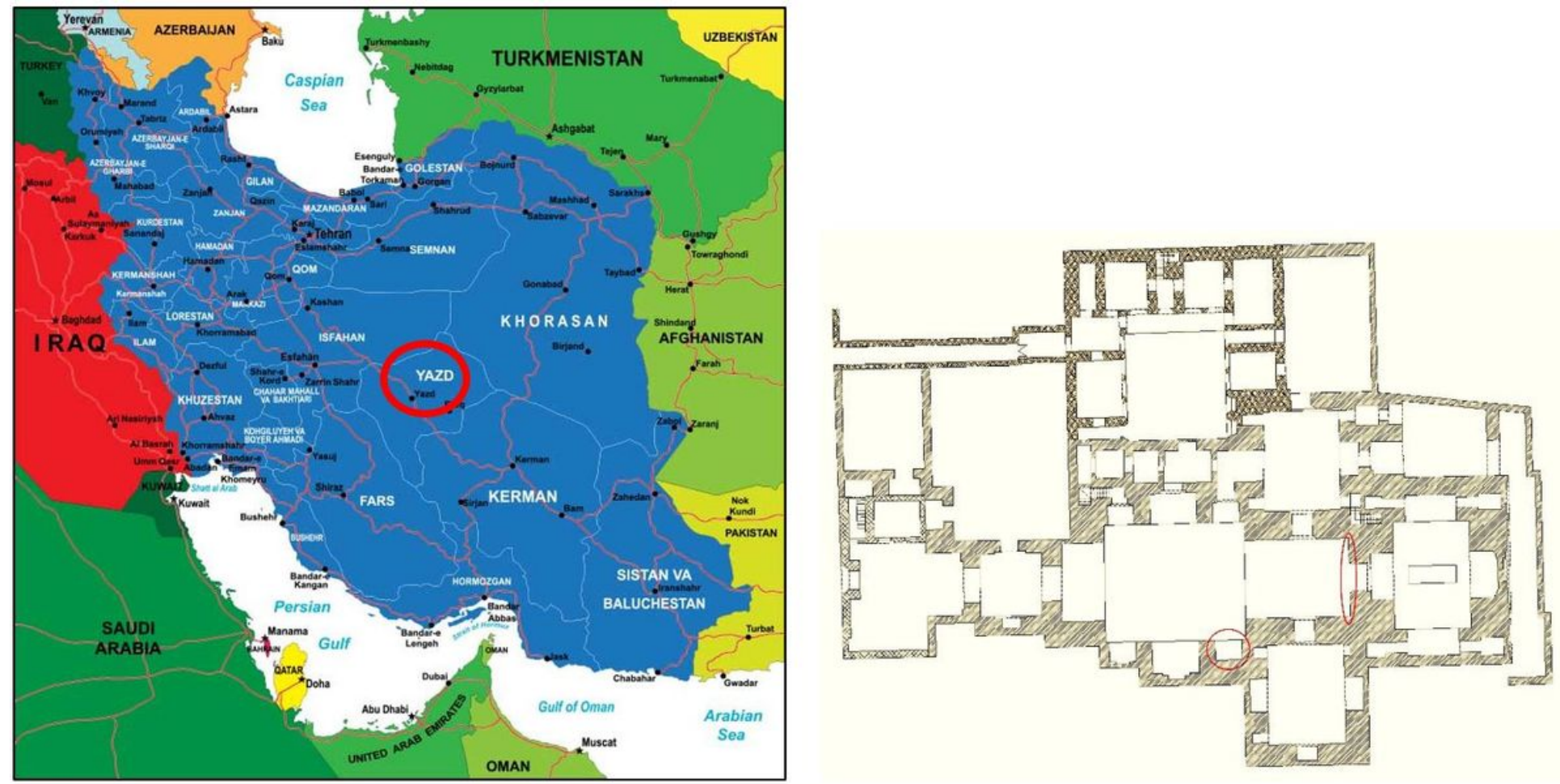


\section{Figure 1}

a. Location of Yazd city in Iran. b. Locations of the parts under study on the building's plan of Seyed Shams al-Din's mausoleum (Source: Yazd Cultural Heritage Deputy). Note: The designations employed and the presentation of the material on this map do not imply the expression of any opinion whatsoever on the part of Research Square concerning the legal status of any country, territory, city or area or of its authorities, or concerning the delimitation of its frontiers or boundaries. This map has been provided by the authors.

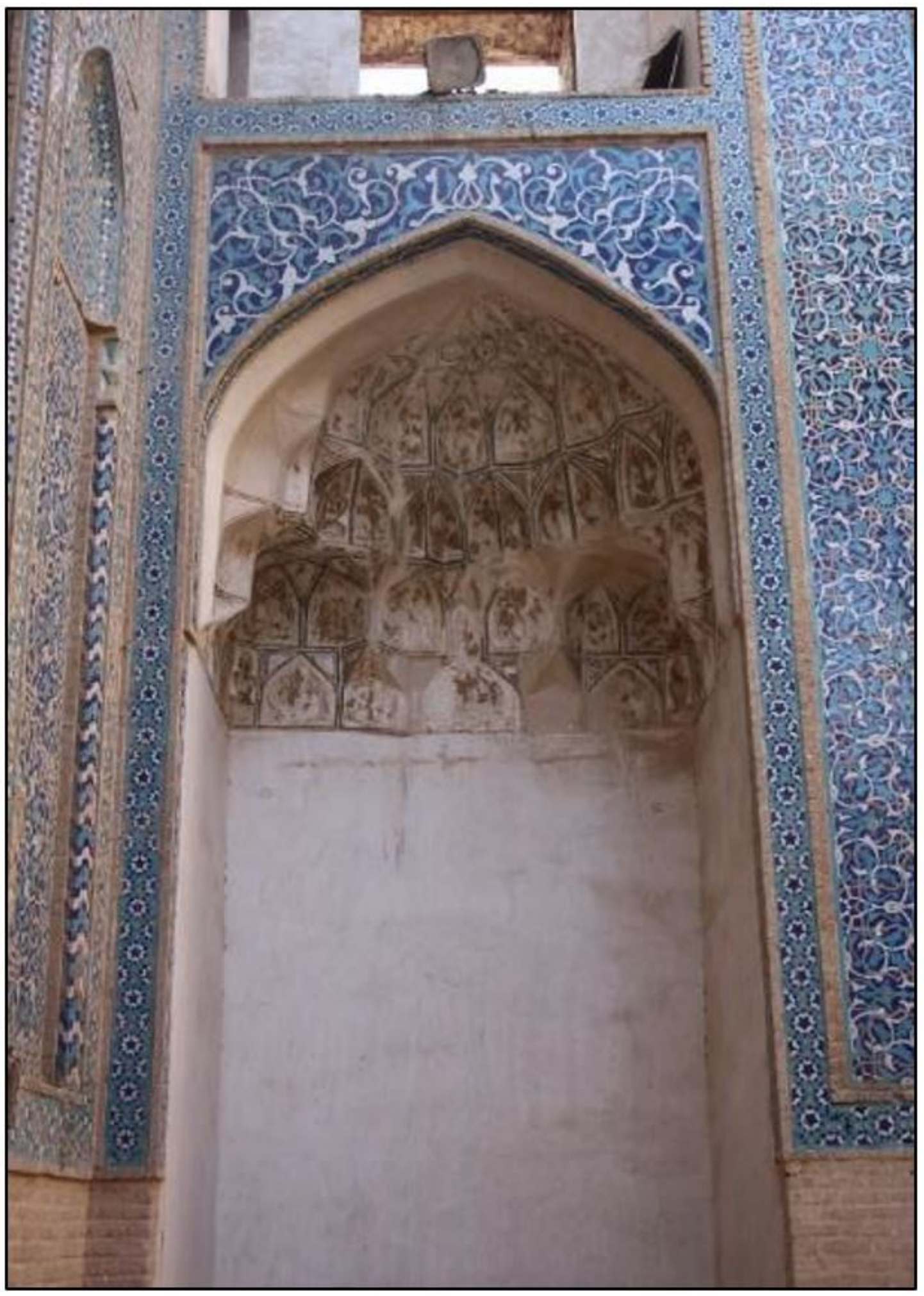


Figure 2

The iwan alcove and the molded gypsum decorations within the Moqarnas

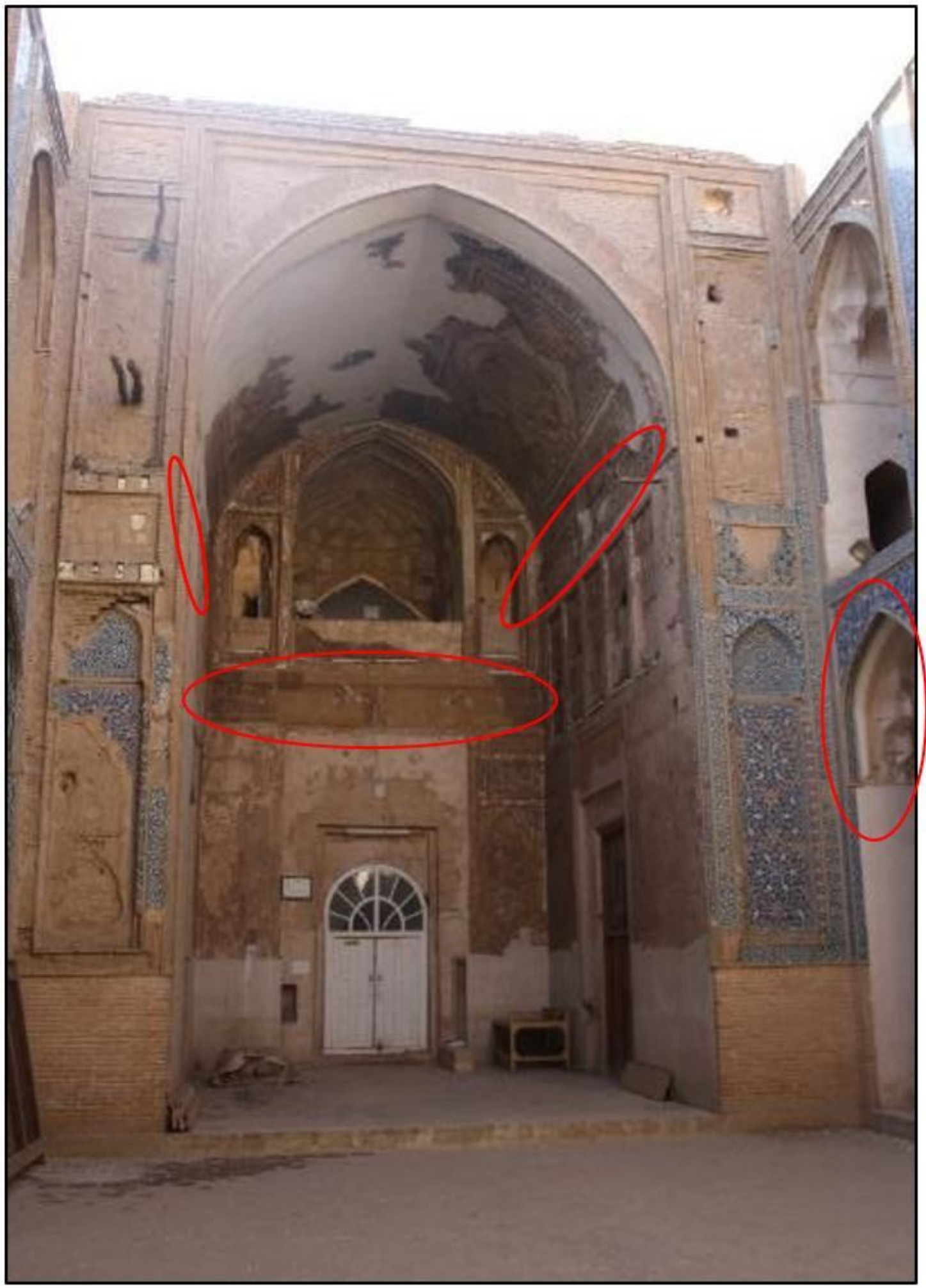

Figure 3

The iwan of the mausoleum, and the location of the gypsum inscription on the three sides 


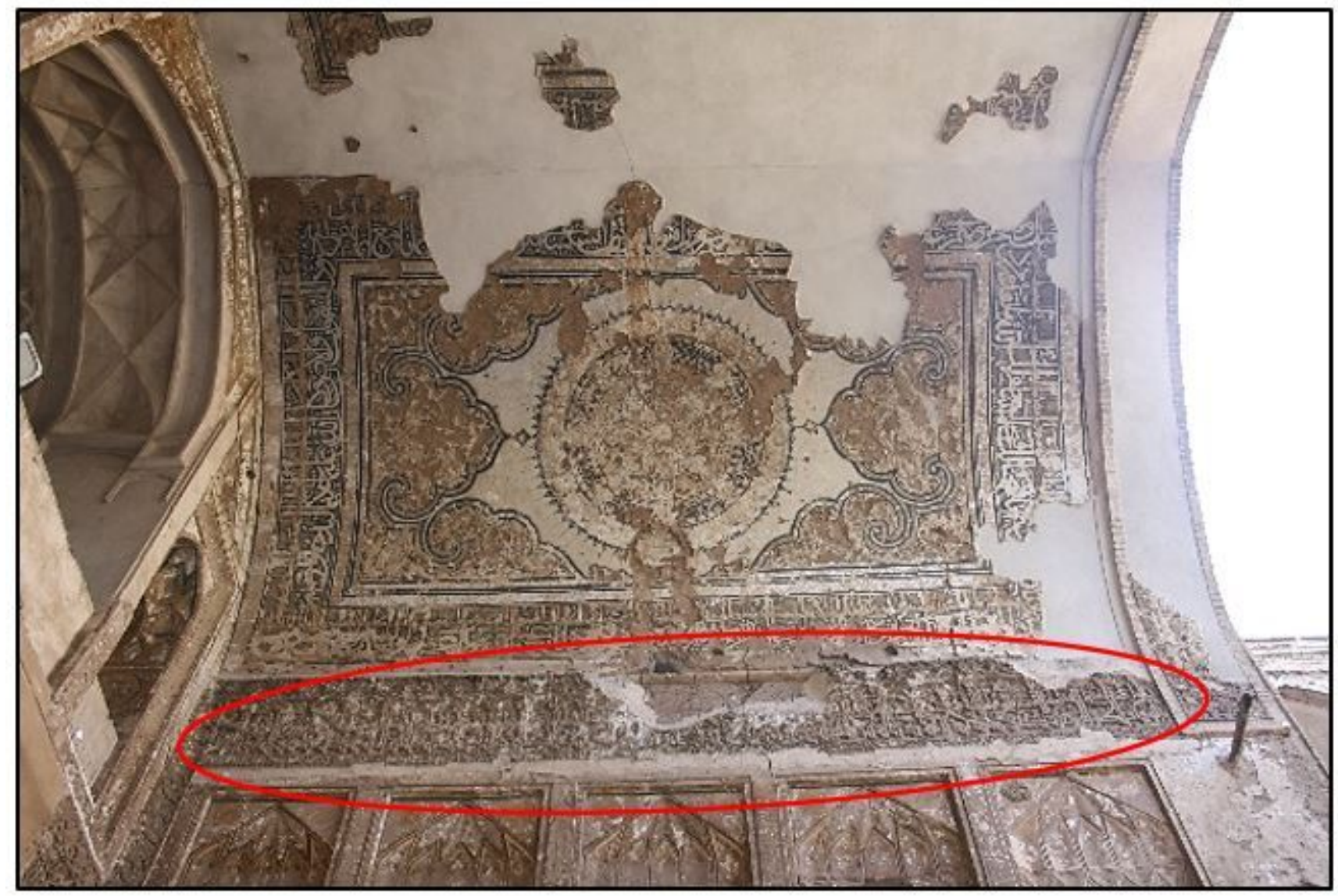

Figure 4

Seyed Shams al-Din Mausoleum: gypsum inscription on the southeast side of the iwan 


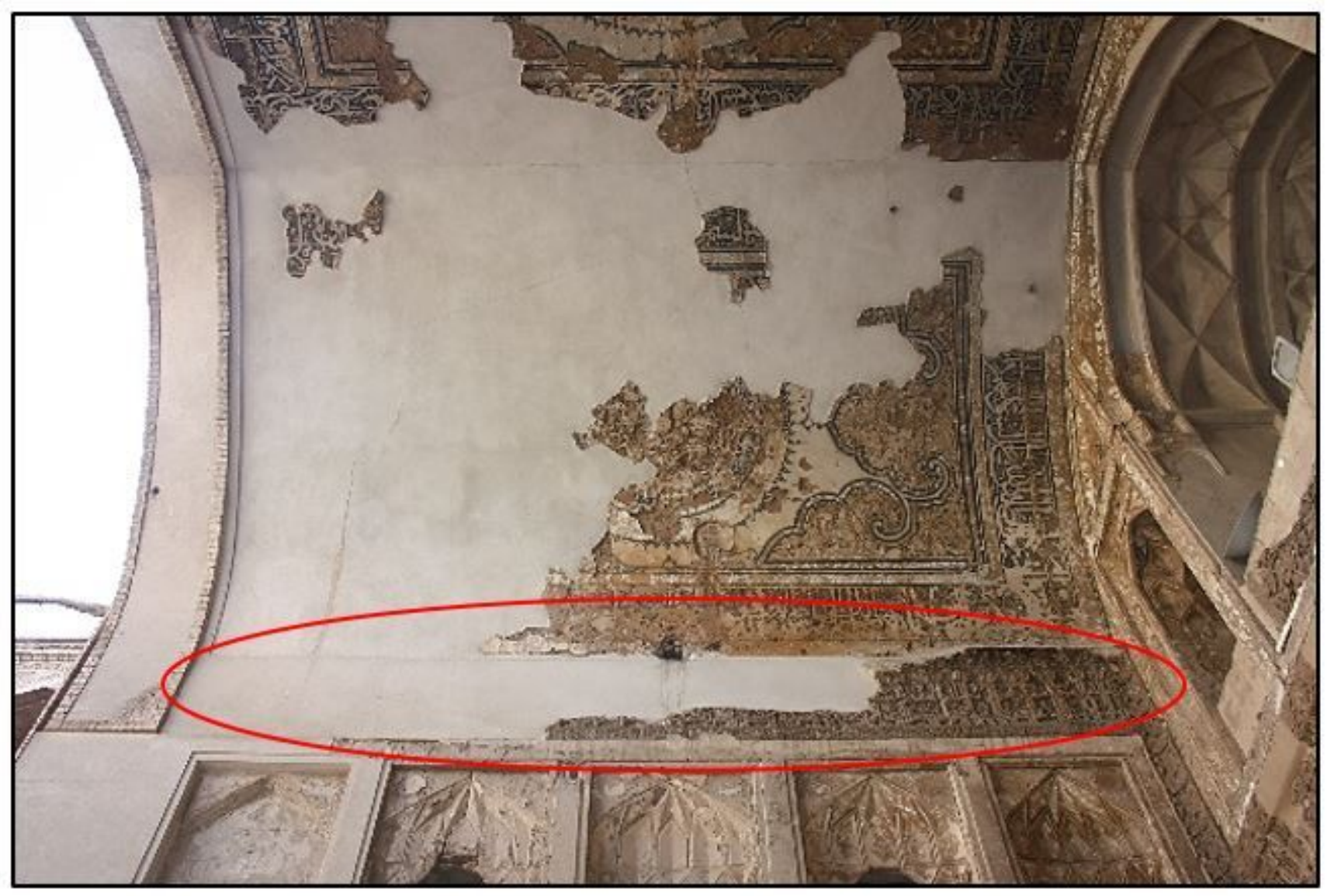

Figure 5

Seyed Shams al-Din Mausoleum: surviving parts of the gypsum inscription on the southeast side of the iwan 


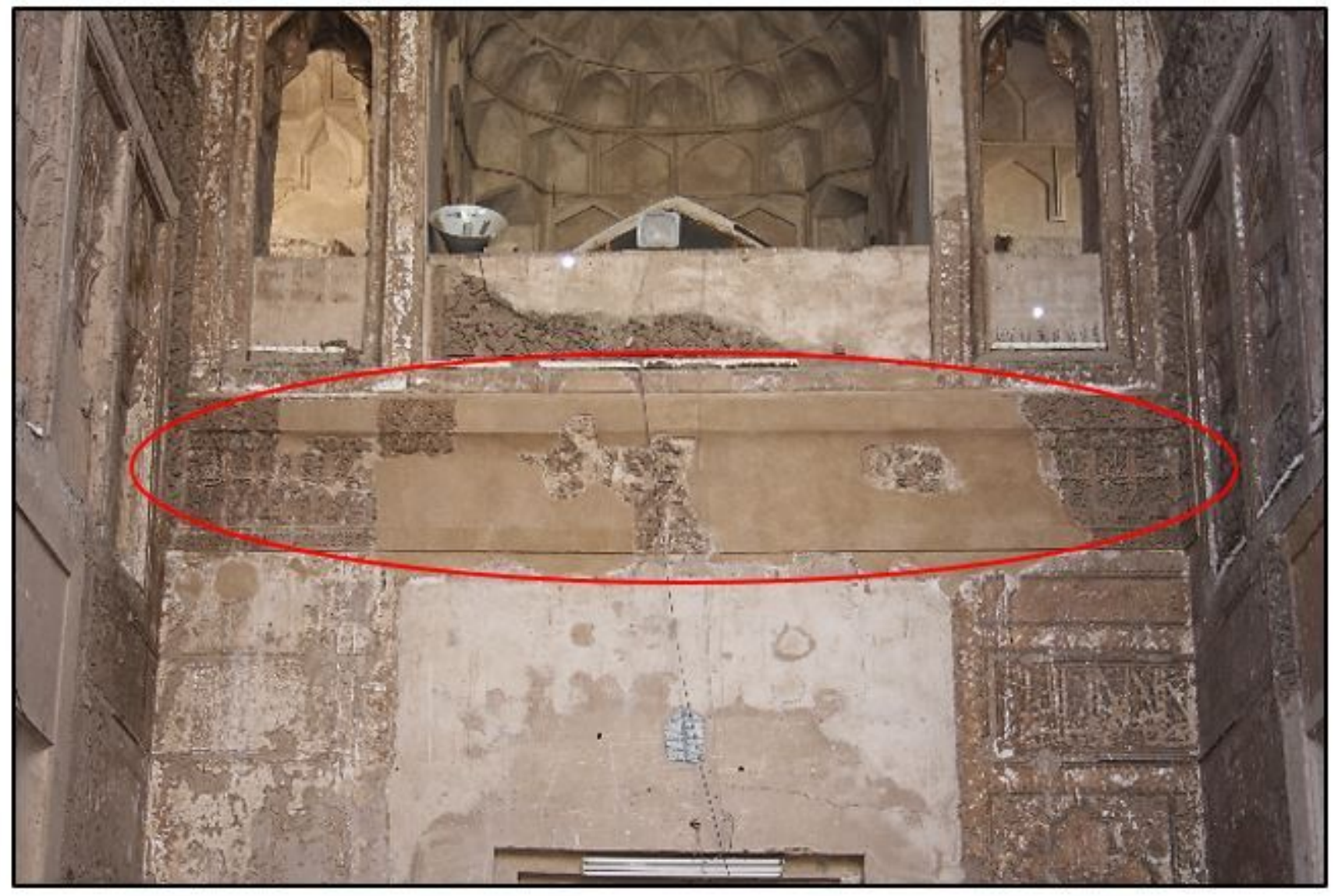

Figure 6

Seyed Shams al-Din Mausoleum: surviving parts of the gypsum inscription on the northeast side of the iwan 


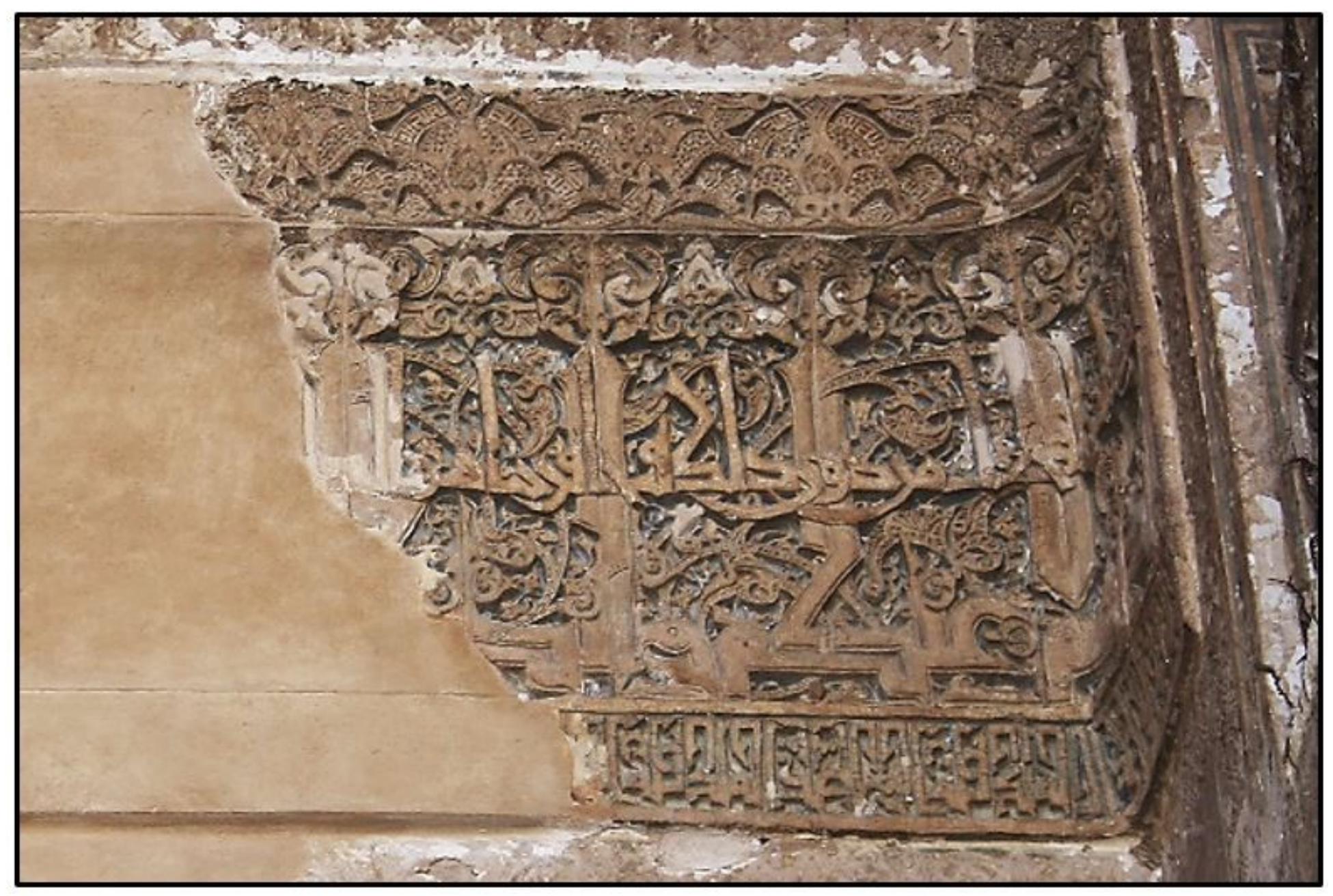

Figure 7

Seyed Shams al-Din Mausoleum: the beginning of the gypsum inscription on the northeast side of the iwan 

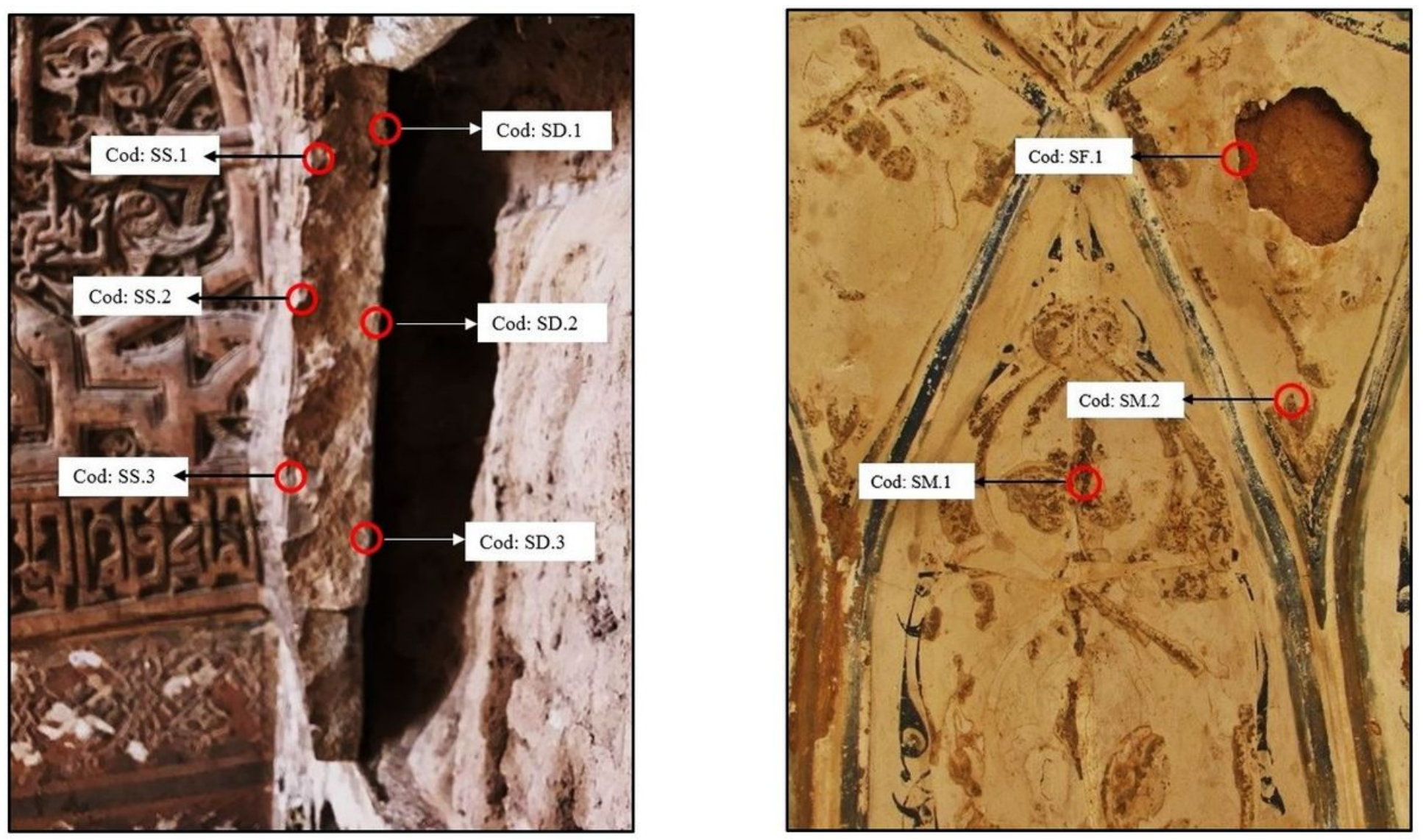

Figure 8

Sampling spots on the Moqarnas area and the gypsum inscription in the northeast side of the iwan of the mausoleum, and coding of the samples

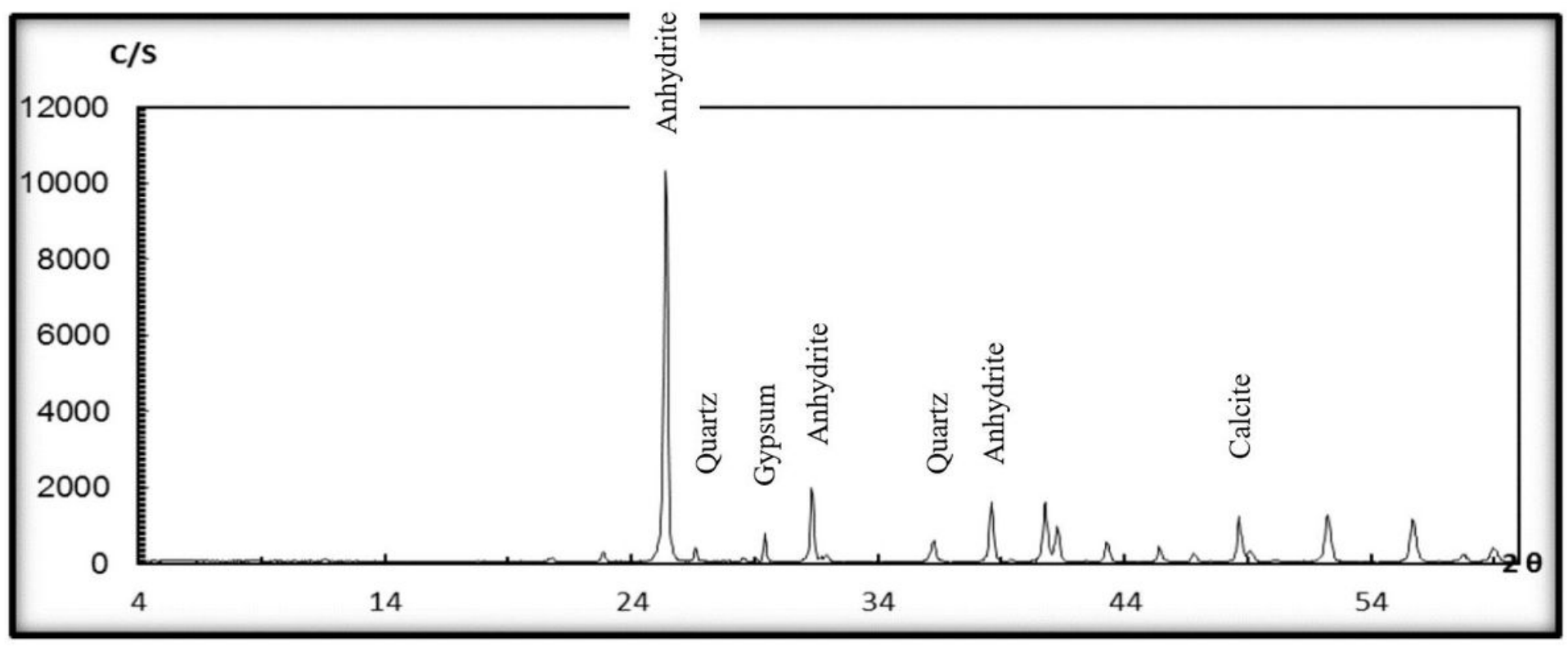

Figure 9

Diffractogram from sample SD.1 


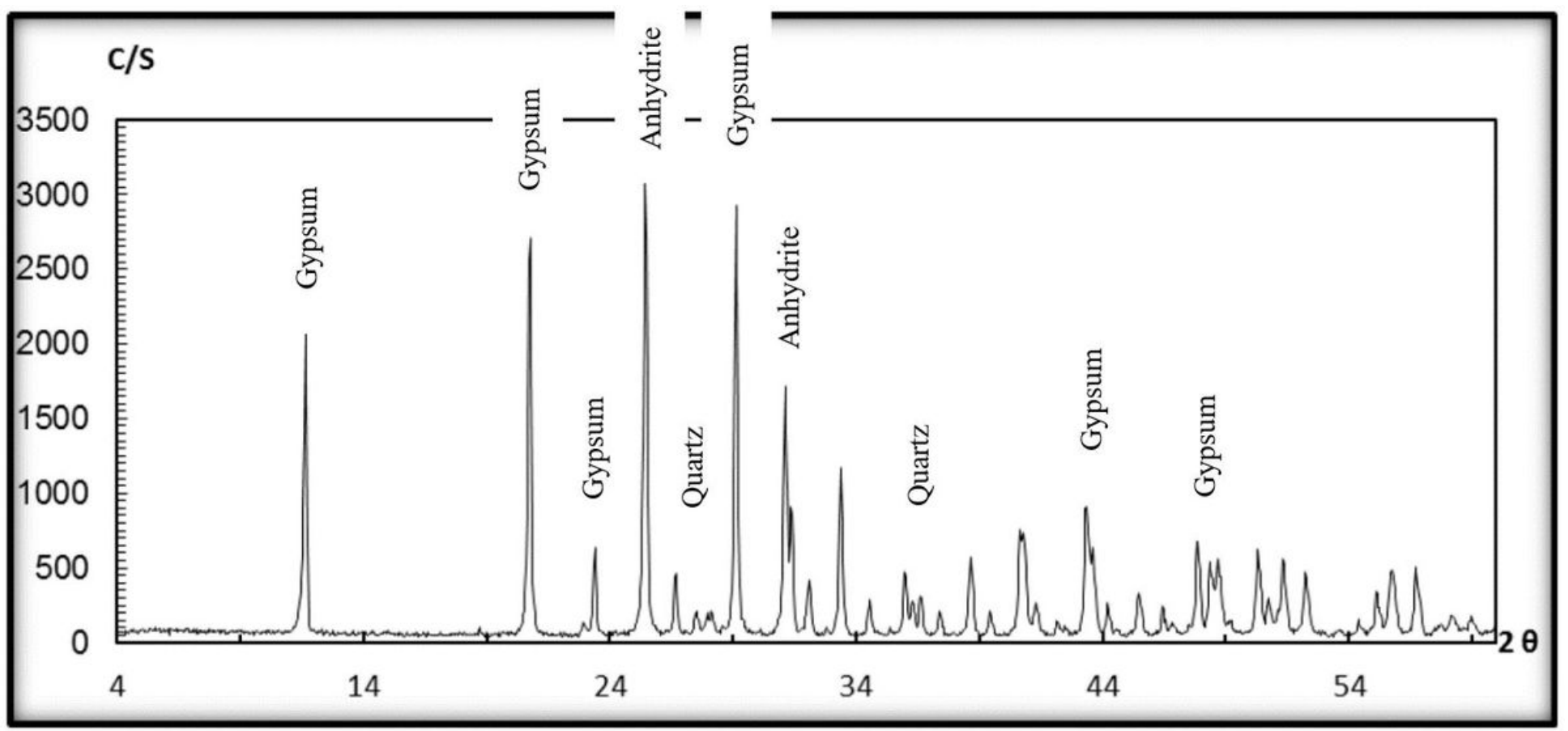

Figure 10

Diffractogram from sample SS.1

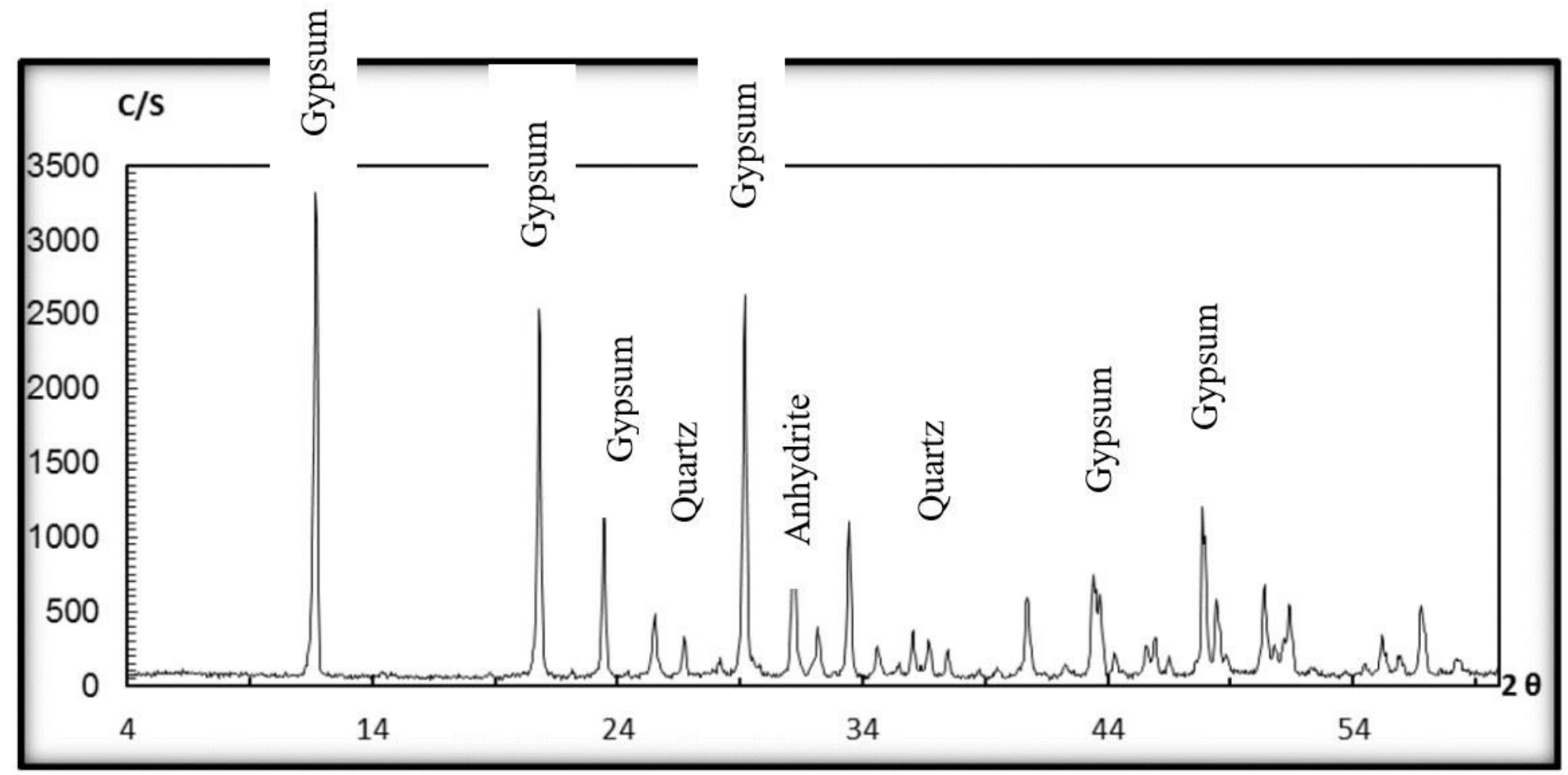

Figure 11

Diffractogram from sample SM.1 